\title{
International Journal for Innovation Education and Research
}

ONLINE ISSN: 2411-2933 PRINT - ISSN: 2411-3123

\section{The impact of transformational leadership in improvement of the organizational capability}

\author{
Silvana Pasovska;Trajko Miceski
}

\begin{abstract}
Transformational leadership has a major impact on the improvement of organizational culture and success. It affects change in cultural characteristics of the individual and improvement of human achievements in all areas, thus creating a long-term positive approach of a person. It results in positive transformation of a person and improvement of its potentials.

The transformational approach has a capacity to make significant change both in individuals and in the organization through adaptation, expectations, aspirations, perceptions and values. Such an approach is based mostly on leader's personality, his character, vision, the power to accept the challenge and on his own example.

Transformational leaders are focused on the "common good" instead of their individual "power bases", they are broad-minded and respect the interests of their followers. With such leaders people are willing to create and innovate and to work harder than expected,.

The paper studies some views on transformational leadership based on charisma, innovation of the companies, producing success and building personalities with durable and unperishable values. This is empirical research on the image of organizations formulated through the statements of managers and employees and presented through tabular, graphical and calculated correlative values.
\end{abstract}

Keyword: leadership, transformation, charisma, innovation, followers, inspiration, creativity, teamwork

Published Date: 2/28/2018

Page.235-246

Vol 6 No 022018

Link: http://ijier.net/ijier/article/view/957 


\title{
The impact of transformational leadership in improvement of the organizational capability
}

\author{
Silvana Pasovska ${ }^{1}$, Trajko Miceski ${ }^{2}$ \\ ${ }^{1}$ Un.St. Kliment Ohridski Bitola, Scientific tobacco institute, Prilep Republic of Macedonia, \\ ${ }^{2}$ Un.Goce Delcev Stip Republic of Macedonia
}

\begin{abstract}
Transformational leadership has a major impact on the improvement of organizational culture and success. It affects change in cultural characteristics of the individual and improvement of human achievements in all areas, thus creating a long-term positive approach of a person. It results in positive transformation of a person and improvement of its potentials.

The transformational approach has a capacity to make significant change both in individuals and in the organization through adaptation, expectations, aspirations, perceptions and values. Such an approach is based mostly on leader's personality, his character, vision, the power to accept the challenge and on his own example.

Transformational leaders are focused on the "common good" instead of their individual "power bases", they are broad-minded and respect the interests of their followers. With such leaders people are willing to create and innovate and to work harder than expected,.

The paper studies some views on transformational leadership based on charisma, innovation of the companies, producing success and building personalities with durable and unperishable values. This is empirical research on the image of organizations formulated through the statements of managers and employees and presented through tabular, graphical and calculated correlative values.
\end{abstract}

Key words: leadership, transformation, charisma, innovation, followers, inspiration, creativity, teamwork

\section{Introduction}

In modern life and work the companies are facing new challenges and changes, to which they must respond in a dynamic and inventive way, mobilizing all available resources in order to maintain their competitive advantages, but they also have to find ways to mobilize their creative potentials to the maximum. Companies need leaders who know how to inspire their followers, to realize their vision and to make the necessary changes willingly, with enthusiasm, as a part of the team that is fully cooperative and committed to the common goal.

The transformational leader is a role model for his employees, who stimulates them to undertake individual initiative and responsibility, to identify their strengths and weaknesses and to constantly work on their personal improvement and innovation. 
The transformational leader is distinguished by personal integrity, trust of the followers, creativity, team orientation, gratitude, learning, responsibility, recognition, etc. Through personal examples and acts he changes the perceptions and expectations and his infectious enthusiasm stimulates followers to exceed normal levels of performance. Transformational leaders, through their personal example, inspire and encourage human resources in the company for their most efficient engagement.

Moreover, they have the potential to manage changes in organizations and their employees in a way that ensures growth, risk management, and minimization of negative effects.

\section{Transformational leadership}

Transformational leadership inspires the employees to observe things from a new perspective, to realize the vision of the company, to develop their potentials and to fulfill their personal goals

through achieving the objectives of the company.

Successful transformational leader prefers clear and attractive visions, creates strategies for achieving the goals by articulating and promoting the visions, his actions are characterized by courage and optimism, he uses the success achieved in earlier stages to gain respect and trust and to increase the optimism among followers, he uses symbols to highlight the key values, creates and modifies positive cultural forms (slogans, symbols, etc.), promotes positive changes, etc ${ }^{1}$.

Transformational leadership increases the incentives for mutual co-operation, turning followers into leaders in their own field of work and leaders into ethical mediators and initiators ${ }^{2}$.

Good transformational leaders inspire confidence in others and transferring this confidence they feel fulfilled. They have a special power to transform both managers of lower levels and followers into persons who will share their preference of durable values. Transformational leaders are focused on "the common good" rather than on their own power bases ${ }^{3}$.

Practicing transformational leadership the leaders become broad-minded and respect the interests of their employees. With such leaders as role-models people are stimulated to work harder than expected. They also show a sense of trust, respect, loyalty and admiration ${ }^{4}$. This process is in line with nature and followers develop different ways to change the environment, improve the current practice and provide mutual support for the team.

Bass proposed the following aspects of transformational leadership, which distinguish it from other leadership concepts ${ }^{5}$ :

- Charisma and good behavior toward others - The leader acts as a role model for other employees. They have to admire, respect and trust him. He puts the interests of the employees ahead of his own and behaves in accordance with ethical codex.

\footnotetext{
1 Yukl, G., 1999. An evaluation of conceptual weaknesses in transformational and charismatic leadership theories. Leadership Quarterly, 10, 285-305; http://dx.doi.org/10.1016/S1048-9843(99)00013-2

2 Burns, J.M. (1978) Leadership. New York. Harper \& Row

3 Sarah Simpson.,(2012). The Styles, Models \& Philosophy of Leadership, Ventus Publishing ApS, p.9

4 Bass B. M. and Avolio B. J.,(1993). Transformational Leadership and Organizational Culture, Public Administration Quarterly, $12,113-121$.

5 Bass, B.M. \& Avolio, B.J., 1994. Improving organizational effectiveness through transformational leadership. Thousand Oaks, CA: Sage Publications
} 
- Inspirational motivation - The leader must always put new challenges to his followers. He presents clear and important goals in a simple way. He builds a strong team spirit, stimulating dedication, optimism and enthusiasm.

- Intellectual stimulation -The leader is always questioning his goals. He approaches the old ideas in a new way and reassess the previous ways of solving the problems. The leader is stimulating careful approach to the problems, rationality, innovation and creativity and he supports intellectual efforts.

- Individualized consideration - The leader pays attention to each person as a specific individual. He cares about the individual followers' needs, achievements and developments and creates opportunities for additional learning. He avoids direct control, supervision and public criticism of followers and accepts the diversity among people.

The goal of transformational leadership is to "transform" people and organizations in a literal sense: to change them in their hearts and minds, to develop a clear and appealing vision, to confirm the objectives, to adjust the behavior to the beliefs, principles and values or, in a word, to make changes that are real, permanent, essential, and evolving. This can be achieved by transformational leader who has a vision, initiative, patience, respect, persistence, courage and faith in oneself.

According to Tom Peters ${ }^{6}$, key characteristics of a successful leader are the following: honesty, competence, modernity, inspiration, fair-mindedness, persistence, imagination, creativity.

Followers of transformational leaders feel trust, loyalty, admiration and respect toward the leader and they are motivated to do more than they originally expected to do.

According to Bass, leaders transform and motivate their followers in a way that ${ }^{7}$ :

1) make them more aware of the importance of task outcomes,

2) induces them to transcend their personal interests for the sake of the organization or the team, and

3) activates their higher-order needs.

In transformational leadership people describe their ideal leader as a role model with whom they want to identify ${ }^{8}$. Transformational leadership as a process by which leaders take action to try to increase the awareness in their associates of what is right and important, to raise their motivational maturity and to move them to go beyond their own self-interests for the good of the group, organization, or society.

\section{The role of transformational leaders}

Transformational leaders are the main factor for transforming the company in organization with better performance. The success of the transformational process depends on their attitudes and values. Some of the key characteristics of transformational leaders are $^{9}$ :

\footnotetext{
6 Tom Peters,2005. Leadership (Essentials), DK Publishing.

7 Bass, B. M. 1996. A new paradigm of leadership: An inquiry into transformational leadership. Alexandria, VA: US Army Research Inst for the Behavioral and Social Sciences.

8 Robert N. Lussier., Christopher F. Achua., Leadership, (2010): Theory, Application, and Skill Development 5th Edition

9 Marlane C. Steinwart, Jennifer A. Ziegler, 2014. Remembering Apple CEO Steve Jobs as a "Transformational Leader": Implications for Pedagogy. Journal of Leadership Education DOI:10.12806/V13/I2/R3
} 
- charisma and personal example,

- promotion and support of innovation,

- conviction that they make right decisions toward positive change of the organization;

- understanding and trust in people and care for the needs of the followers;

- believe in true values and act in accordance with a core set of values;

- lifelong learning and profound analysis of practical situations,

- flexibility and openness to the contemporary achievements in science, recognition of positive values,

- strong power of observation, inclination toward disciplined thinking and analysis of problems

- visionarity and belief in positive aims, etc.

One of the key qualities of the transformational leader is his charisma. Without charisma one cannot become transformational leader. This trait, however, is not enough for the leader to carry out the transformational process. ${ }^{10}$

Charismatic leaders are able to arouse strong emotions among followers and identification with the leader, but it can be also a trait of autocratic leadership, whereas the aim of the transformational leadership is not only to secure loyalty, but also attachment of the followers to the idea of their leader.

\section{Empirical research}

The aim of the theoretical and empirical research is to look at the theory and practice and to perceive the situation by applying transformational leadership in the research firms.

The main hypothesis in this paper is the assertion that: transformation leaders are a key factor in transforming the organization and the employees into higher value entities. The methods used in this research are: analysis, survey and statistical analysis, processing and calculation of data. The survey as a method of research was conducted by formulating questionnaires with standardized questions for the managers and for the employees, divided into several groups of statements. The collected data is statistically processed, which enables the ranking of data and their presentation through a tabular and graphical display, in order to provide more detailed conclusions from the conducted practical research.

Although the questionnaires were distributed to 150 managers and employees, however, 31 managers and 102 employees answered all questions.

In the empirical research, the $\mathrm{x}^{2}$-test and the coefficient of contingency $(\mathrm{C})$ were used, in order to understand the relevance of the statements of the examined managers and employees. As one of the most commonly used tests, the $\mathrm{x}^{2}$-test was used to examine the differences between the group variance of the investigated and theoretical frequencies. ${ }^{11}$

Below is a tabular and graphical presentation of the received and processed data from all the questions that are the subject of this research, as well as their interpretation.

\footnotetext{
10 Timothy A. Judge, at all, 2006. Charismatic and Transformational leadership.Organisationpsichologie 50 203-214.

11 Miceski Trajche,(2009)Health statistics and data analysis, University of “Goce Delchev", Shtip, page 154-191
} 
The first question was: Does the manager distinguished himself with charisma and is he an example for the employees?

Table 1. Tabular presentation of the answers of the examined managers after the first question

\begin{tabular}{|c|c|c|c|c|}
\hline \multirow[t]{2}{*}{ Question 1} & \multirow[t]{2}{*}{ Answer } & Manager & \multicolumn{2}{|c|}{ Employees } \\
\hline & & $\begin{array}{l}\mathrm{N} \\
\%\end{array}$ & $\begin{array}{l}\mathrm{N} \\
\%\end{array}$ & \\
\hline \multirow{3}{*}{$\begin{array}{l}\text { Does the manager distinguish himself } \\
\text { with charisma and is he an example } \\
\text { for the employees? }\end{array}$} & Yes & $\begin{array}{l}25 \\
81 \\
\end{array}$ & 54 & 53 \\
\hline & $\begin{array}{l}\text { No } \\
\text { No answer }\end{array}$ & $\begin{array}{l}1 \\
3\end{array}$ & $\begin{array}{l}12 \\
36\end{array}$ & 12 \\
\hline & Total & $\begin{array}{l}5 \\
16 \\
31 \\
100\end{array}$ & $\begin{array}{l}35 \\
102 \\
100\end{array}$ & \\
\hline \multicolumn{5}{|l|}{ Calculated value of $X^{2}=18,329$} \\
\hline$C=0,290$ & & & & \\
\hline
\end{tabular}

The answers to this question are shown in Graph 1:

Question No. 1. Does the manager distinguish himself with charisma and is he an example for the employees?

\begin{tabular}{|l|l|}
\hline Managers & Employees \\
\hline
\end{tabular}




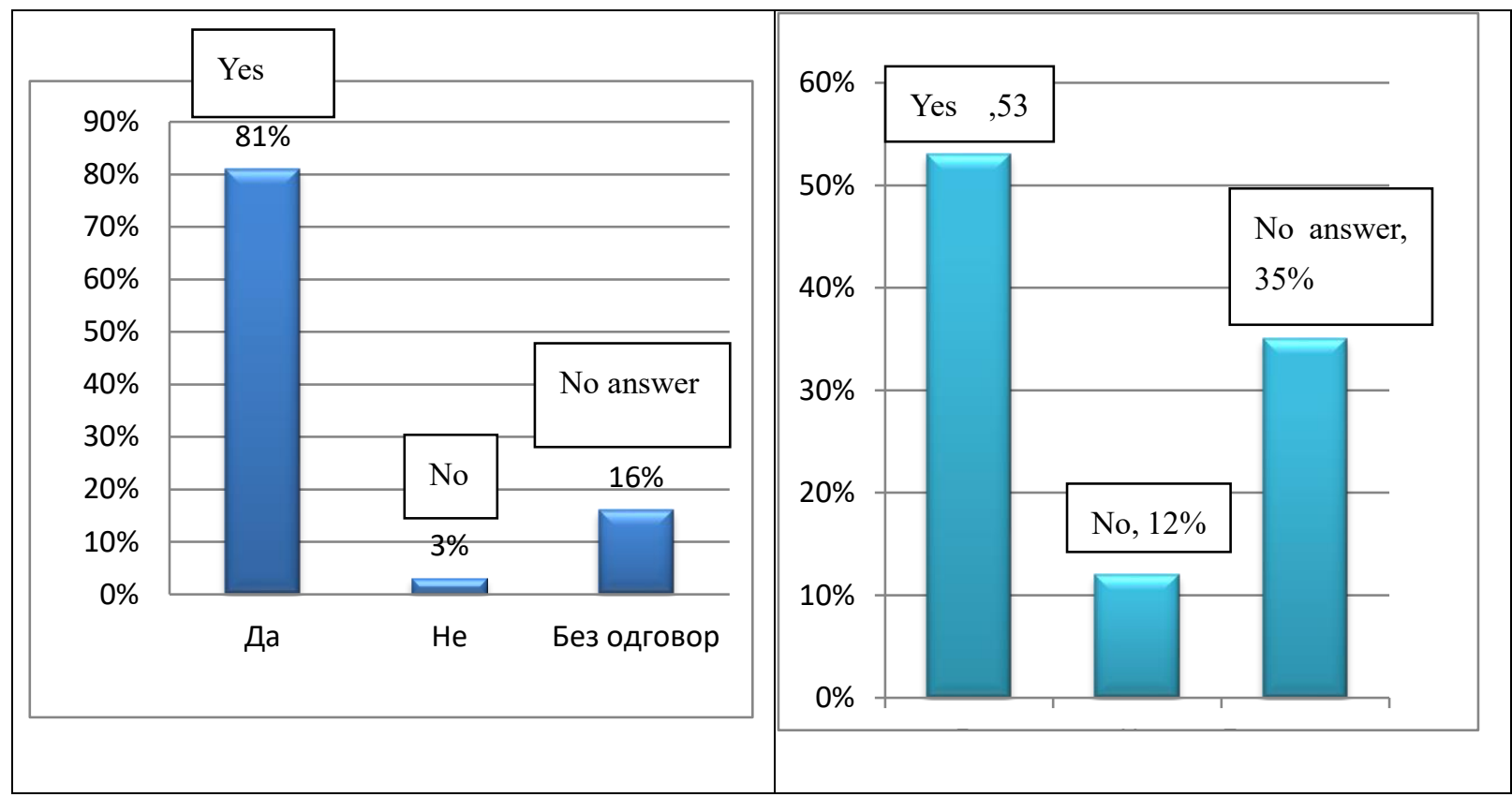

Figure 1. Graphic presentation of the answers of the examined managers after the first question

From the tabular and the graphic display, it can be seen that $81 \%$ of the managers on the first question in the surveyed companies consider that they have real capabilities such as: charisma and that they are an example for the employees, $3 \%$ of them answered negative, while $16 \%$ remained unanswered.

While $53 \%$ of the total surveyed employees believe that their managers are characterized with charisma and that they are an example for the employees, $12 \%$ have declined negatively, and $35 \%$ have remained unanswered.

The calculated value of the $\mathrm{X}^{2}$ test for this question is 18,329 which is greater than the tabular value of $\mathrm{X}^{2}$ of 5,991, which can be concluded that the answers of the managers and the employees do not match with this question. The coefficient of contingency is 0.290 indicating a very weak interdependence between the examined variables.

The second question was: Does the manager inspire and motivate the employees?

The answers of the examined managers and employees are shown in the table and in the graph below. 
Table 2. Tabular presentation of the answers of the examined managers after the second question

\begin{tabular}{|c|c|c|c|c|}
\hline \multirow[t]{2}{*}{ Question 2} & \multirow[t]{2}{*}{ Answer } & Manager & \multicolumn{2}{|c|}{ Employees } \\
\hline & & $\begin{array}{l}\mathrm{N} \\
\%\end{array}$ & $\begin{array}{l}\mathrm{N} \\
\%\end{array}$ & \\
\hline \multirow{4}{*}{$\begin{array}{l}\text { Does the manager inspire and } \\
\text { motivate the employees? }\end{array}$} & Yes & 28 & 51 & 50 \\
\hline & $\mathrm{No}$ & 90 & 12 & 12 \\
\hline & No answer & $\begin{array}{l}1 \\
3\end{array}$ & 39 & \\
\hline & Total & $\begin{array}{l}2 \\
7 \\
31 \\
100\end{array}$ & $\begin{array}{l}38 \\
102 \\
100\end{array}$ & \\
\hline \multicolumn{5}{|l|}{$\begin{array}{l}\text { Calculated value of } X^{2}=38,184 \\
C=0,400\end{array}$} \\
\hline
\end{tabular}

The answers to this question are shown in Graph 2:

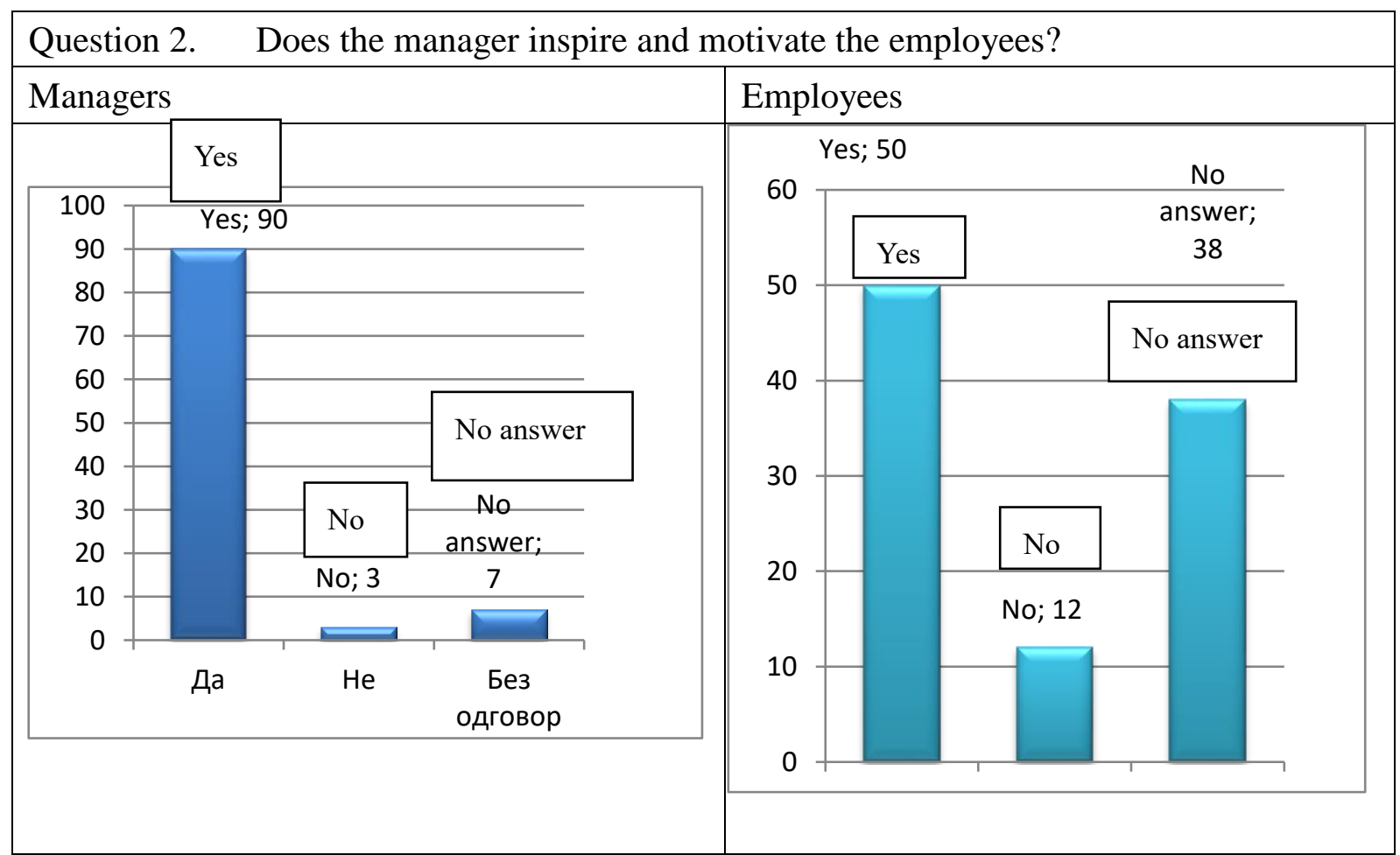

Graph 2. Graphic

presentation of the percentage representation of the answers of the managers and the employees on the second question. 
From Table 2 and Graph 2 it can be seen that $90 \%$ of the managers, and $50 \%$ of the employees share the same opinion. On the same question, they thought otherwise, i.e. $3 \%$ of the managers and $12 \%$ of the employees answered negatively. $7 \%$ of the managers and $38 \%$ of the employees remain unanswered.

The calculated value of the $\mathrm{X}^{2}$ test for this question is 30,184 which is greater than the tabular value of $\mathrm{X}^{2}$ of 5,991, whereby the answers of the managers and the employees to this question do not match. The coefficient of contingency is 0,400 indicating very weak interdependence between the examined variables. The third question: Does the manager approach the problem solving carefully, and encourages inventiveness and creativity among employees?

Table 3. Tabular presentation of the percentage representation of the answers of the examined managers after the third question

\begin{tabular}{|c|c|c|c|c|}
\hline \multirow[t]{2}{*}{ Question 3} & \multirow[t]{2}{*}{ Answer } & Manager & \multicolumn{2}{|c|}{ Employees } \\
\hline & & $\begin{array}{l}\mathrm{N} \\
\%\end{array}$ & $\begin{array}{l}\mathrm{N} \\
\%\end{array}$ & \\
\hline \multirow{4}{*}{$\begin{array}{l}\text { Does the manager approach the } \\
\text { problem solving carefully, and } \\
\text { encourages inventiveness and } \\
\text { creativity among employees? }\end{array}$} & Yes & $\begin{array}{l}29 \\
94\end{array}$ & 55 & 54 \\
\hline & No & & 10 & 10 \\
\hline & No answer & $\begin{array}{l}0 \\
0\end{array}$ & 37 & \\
\hline & Total & $\begin{array}{l}2 \\
6 \\
31 \\
100\end{array}$ & $\begin{array}{l}36 \\
102 \\
100\end{array}$ & \\
\hline \multicolumn{5}{|l|}{ Calculated value of $X^{2}=42,239$} \\
\hline
\end{tabular}

The answers to this question are shown in Graph 3:

Question 3. Does the manager approach the problem solving carefully, and encourages inventiveness and creativity among employees?

\begin{tabular}{|l|l}
\hline Managers & Employees \\
\hline
\end{tabular}




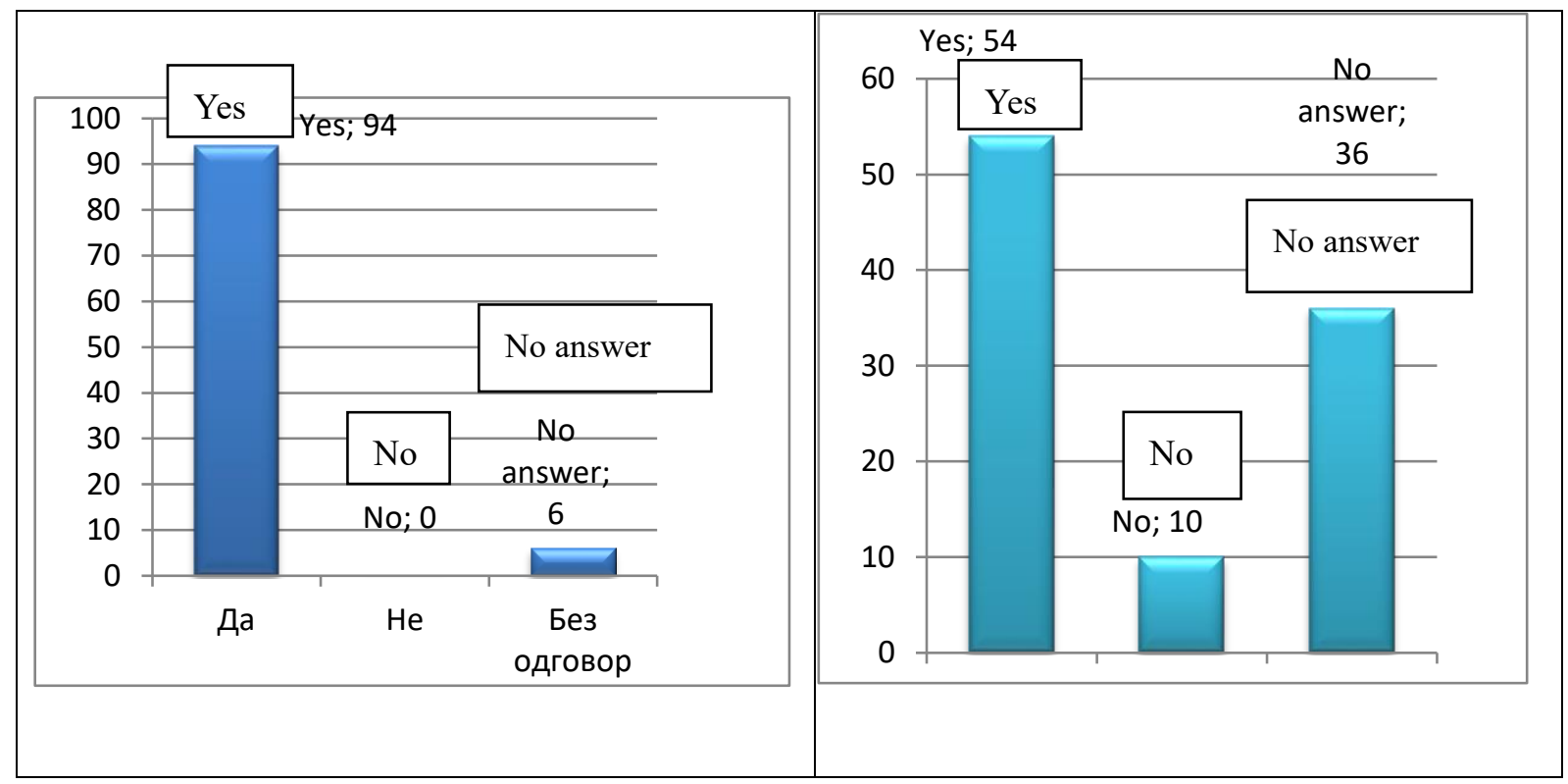

Graph 3. Graphic presentation of the percentage representation of the answers of the managers and the employees on the third question.

The table and graph show that out of the total number of 31 surveyed managers, $94 \%$ answered positively that the manager (leader) with a personal example motivates and inspires employees towards positive changes in the behavior and operation of the firm, and out of 102 of the total surveyed employees, 54\% share the positive opinion on this question, while $0 \%$ of the surveyed managers answered this question negatively, ie with no, and $10 \%$ of the surveyed employees answered in the same way or negatively. Unanswered remain $6 \%$ of the surveyed managers and $36 \%$ of the surveyed employees. The calculated value of the $\mathrm{X}^{2}$ test for this question is 42,239 which is greater than the tabular value, whereby the answers of the managers and the employees to this question do not match. The coefficient of contingency is 0,418 indicating very weak interdependence between the examined variables.

The presentation enables us to see that in the surveyed companies it cannot be said that the transformational leadership is applied, or, it can be concluded that the manager does not approach carefully to solve the problems, and encourages the inventiveness and creativity of the employees.

The fourth question: Does the manager pay attention to the person, treat each individual as a specific individual, knowing the diversity among people? 
Table 4. Tabular presentation of the percentage representation of the answers of the examined managers after the fourth question.

\begin{tabular}{|c|c|c|c|c|}
\hline \multirow[t]{2}{*}{ Question 4} & \multirow[t]{2}{*}{ Answer } & Manager & \multicolumn{2}{|c|}{ Employees } \\
\hline & & $\begin{array}{l}\mathrm{N} \\
\%\end{array}$ & $\begin{array}{l}\mathrm{N} \\
\%\end{array}$ & \\
\hline \multirow{4}{*}{$\begin{array}{l}\text { Does the manager pay attention to the } \\
\text { person, treat each individual as a } \\
\text { specific individual, knowing the } \\
\text { diversity among people? }\end{array}$} & Yes & $\begin{array}{l}30 \\
97\end{array}$ & 49 & 48 \\
\hline & $\overline{\text { No }}$ & & 13 & 13 \\
\hline & No answer & $\begin{array}{l}0 \\
0\end{array}$ & 40 & 39 \\
\hline & Total & $\begin{array}{l}1 \\
3 \\
31 \\
100\end{array}$ & $\begin{array}{l}102 \\
100\end{array}$ & \\
\hline \multicolumn{5}{|l|}{$\begin{array}{l}\text { Calculated value of } X^{2}=60,416 \\
C=482\end{array}$} \\
\hline
\end{tabular}

The answers to this question are shown in Graph 4:

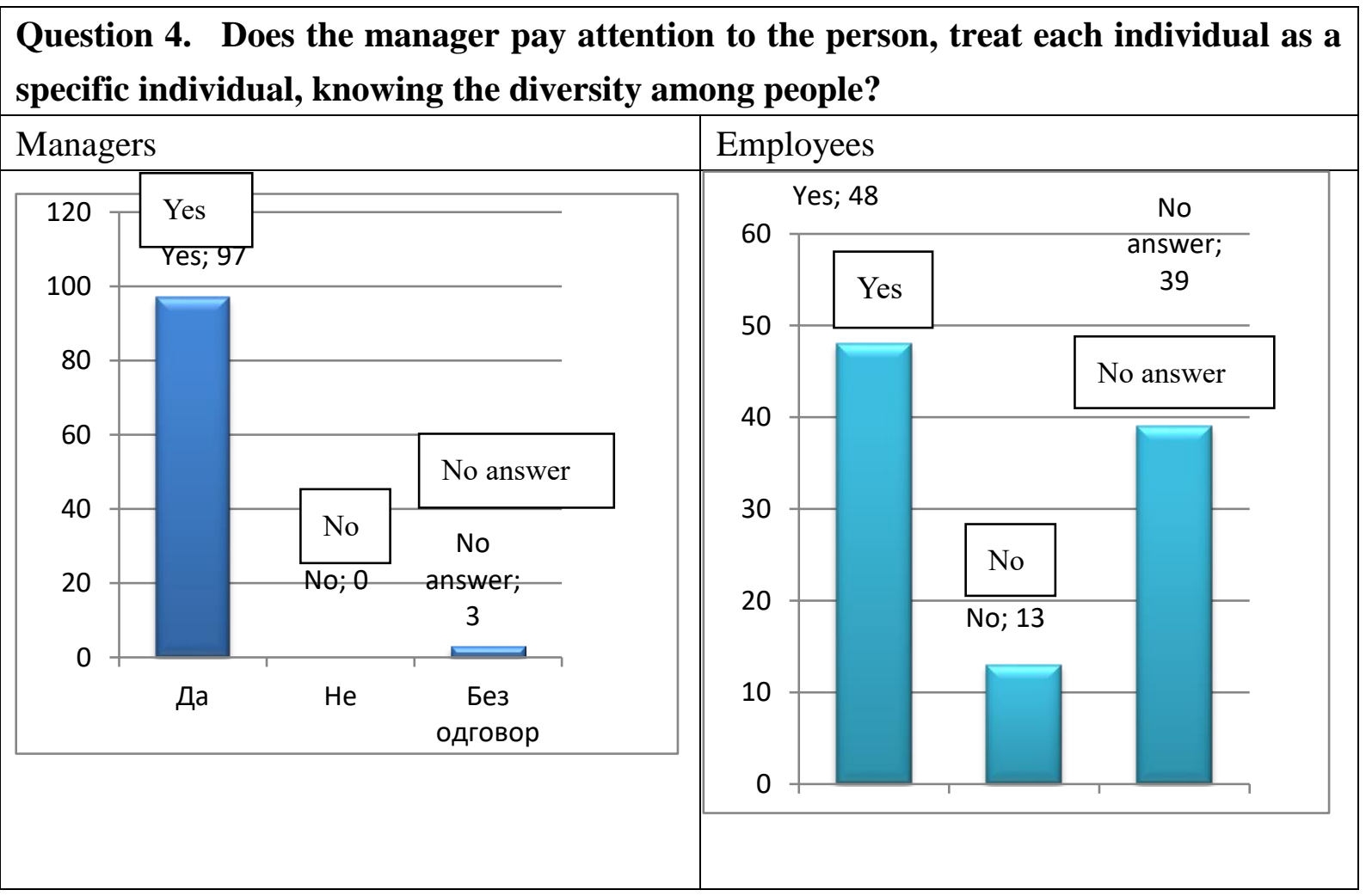


presentation of the percentage representation of the answers of the managers and the employees on the fourth question.

The table and graph show that out of the total number of 31 surveyed managers, $97 \%$ answered positively that the manager pays attention to the person, treat each individual as a specific individual, knowing the diversity among people, and out of 102 of the total surveyed employees, $48 \%$ share the positive opinion on this question, while $0 \%$ of the surveyed managers answered this question negatively, i.e. with no, and $13 \%$ of the surveyed employees answered in the same way or negatively. Unanswered remain $3 \%$ of the surveyed managers and $39 \%$ of the surveyed employees.

The calculated value of the $\mathrm{X}^{2}$ test for this question is 60,416 which is greater than the tabular value. The coefficient of contingency is 0,482 indicating moderate interdependence between the examined variables. The presentation enables us to see that in the surveyed companies it cannot be said that the transformational leadership is applied, or, it can be concluded that the principles of the transformational leadership are not sufficiently recognized and applied.

From all this it can be concluded that the results of this empirical research show that in most cases, the basic hypothesis that transformational leaders are a key factor in transforming the organization and the employees into higher value entities is not confirmed. It points to the properly selected area of research and directs to greater training i.e. upgrading especially for managers, but also for employees.

\section{Conclusion}

Transformational leadership is closer to the prototype of leadership that people have in mind when they describe their ideal leader, and it is likely to provide an example that the subordinates want to identify with. Transformational leadership contributes to greater motivation and performance among followers compared to those of transactional leadership, but the effective leaders use a combination of the two types of leadership. The aim of transformational leadership is to "transform" people and organizations in the literal sense - to change them in the heart and mind; to increase vision, views and understanding; to clarify the goals; to act in accordance with beliefs, principles, and values. Transformational leadership is a process in which leaders undertake activities in which they try to raise awareness among their supporters of what is right and important, to raise their "motivational maturity to move beyond their own interests," for the benefit of the group, organization, or society. Such leaders provide a sense of goal for their supporters, a goal that is beyond the simple exchange of rewards for the effort.

Transformation leaders are proactive in many different and unique ways. These leaders are trying to optimize the development, not just the performance. Development involves the maturation of ability, motivation, attitudes and values. Such leaders want to raise the level of maturity for the needs of their supporters (from security needs, to the needs for achievement and their own development). They persuade their supporters to strive towards a higher level of achievement, as well as to higher levels of moral and ethical standards. Through the development of their supporters, they optimize the development of their organization. The high performances of the supporters build high performances of the organizations. 


\section{References}

1. Yukl, G., 1999. An evaluation of conceptual weaknesses in transformational and charismatic leadership theories. Leadership Quarterly, 10, 285-305; http://dx.doi.org/10.1016/S1048-9843(99)00013-2

2. Burns, J.M. (1978) Leadership. New York. Harper \& Row

3. Sarah Simpson.,(2012). The Styles, Models \& Philosophy of Leadership, Ventus Publishing ApS, p.9

4. Bass B. M. and Avolio B. J.,(1993). Transformational Leadership and Organizational Culture, Public Administration Quarterly, 12,113-121.

5. Bass, B.M. \& Avolio, B.J., 1994. Improving organizational effectiveness through transformational leadership. Thousand Oaks, CA: Sage Publications

6. Tom Peters,2005. Leadership (Essentials), DK Publishing.

7. Bass, B. M. 1996. A new paradigm of leadership: An inquiry into transformational leadership. Alexandria, VA: US Army Research Inst for the Behavioral and Social Sciences.

8. Robert N. Lussier., Christopher F. Achua., Leadership, (2010): Theory, Application, and Skill Development 5th Edition

9. Marlane C. Steinwart, Jennifer A. Ziegler, 2014. Remembering Apple CEO Steve Jobs as a "Transformational Leader": Implications for Pedagogy. Journal of Leadership Education DOI:10.12806/V13/I2/R3

10. Timothy A. Judge, at all, 2006. Charismatic and Transformational leadership.Organisationpsichologie 50 203-214.

11. Miceski Trajche,(2009)Health statistics and data analysis, University of "Goce Delchev", Shtip, page 154-191 